\title{
Modernization and Social Change among Adolescence
}

\author{
Trupti Ambalal Chandalia ${ }^{1}$
}

\section{ABSTRACT:}

The main purpose of this research was to find out the mean difference between modernization and social change of rural and urban Adolescence. The total 480 sample were taken, out of 480 sample 240 were rural Adolescence \& 240 urban adolescence were taken from Rajkot and Junagadh District. The research tool for comprehensive modernization, Prof. S. P. Ahluwalia \& Dr. Ashok Kalia comprehensive modernization inventory (1985) was used for social change, Dr. Rama Tiwari, Agra, Miss Romapal and Miss Radha Pandey's social change inventory used. Here Gujarati Adaption used t-test was applied to check the difference of modernization and social change. Check relation Karl-person ' $r$ ' method used. Result revels that significant difference in Modernization and social change with respect both rural and urban adolescence. While the corelation between modernization and social change reveals positive significant difference. that means modernization are more so social change are more.

Keywords: Modernization, Social Change and Adolescent

Human society has changed much over the last centuries and this process of Modernization has pro fondly affected our lives. Modernization is the process of changing the conditions of a society. Today we live in a modern age where we want to get things easily done change is the low of nature and this change is evident in each and every sphere of man's life. This change is so fast varietal and spontaneous as our priorities, aims, goals of life are changing and directed towards the world of competition. The fast developing technology rich information system and the vast expansion of knowledge has brought and the corresponding changes in the lives of the people the change in the society is possible through modernization, which include besides technological advancement, change in thinking beliefs and customs etc.

From the beginning of life till now life has been changing. Change is the law of nature, and changes in society are always taking place. At times there changes are slow. Sometime they are so slow that people do not even perceive them. However, there are times when they are also rapid and drastic. All spheres of living things are changing. The word modernization is derived from Latin word 'mound' means Modern. Modernization as a form of cultural response attributes which are basically universalistic and evolutionary.

\footnotetext{
${ }^{1} \mathrm{Ph}$. D. Research Scholar, Department of Psychology, Saurashtra University

(C) 2015 I T Chandalia; licensee IJIP. This is an Open Access Research distributed under the terms of the Creative Commons Attribution License (http://creativecommons.org/licenses/by/2.0), which permits unrestricted use, distribution, and reproduction in any Medium, provided the original work is properly cited.
} 


\section{Modernization and Social Change among Adolescence}

Modernization is generally regarded as a process of change. Change of traditional society into a society based on science and technology modernization can best be defined as the process of transforming the old traditional society and nations to the modernity in the fields of social, political, cultural and educational advancement.

Modernization mean the appearance of 'Modes' of social life of organization which emerged in Europe from about the seventeenth century on words and which subsequently became more or less worldwide in their influence (Giddens, 1991) modernization theory states that the economy. Social condition and culture values of a society are to large extent structurally and functionally linked and change relatively predictable ways (Rostow-1971).

\section{OBJECTIVES:}

The main objectives of this study are as under:

1. To study the modernization and social change of the rural \& urban Adolescence.

2. To study the relationship between the modernization and social change of the rural \& urban Adolescence.

\section{HYPOTHESIS:}

Two related objectives of this study hypothesis were us under.

H1. There is no significant difference in the mean scores of the modernization among rural \& urban Adolescence.

$\mathrm{H} 2$ "There is no significant difference in the mean scores of social change among rural and urban adolescence.

H3 There is no correlation between the modernization and social change of the Adolescence.

\section{Samples:}

According to the purpose of present study a total of 480 samples has been selected. There were 240 rural Adolescence and 240 urban Adolescence taken as a sample (who were taken from Rajkot District, Gujarat, India)

\section{Tools:}

1. Comprehensive modernization inventory (Prof. S. P. Ahluwalia + Dr. Ashok Kalia1985).

2. Social change Inventory (Dr. Rama Tiwari - Agra, Miss Roma Pala + Miss RadhaPandey)

\section{RESULT AND DISCUSSION:}

The main objective of present study was to a study of modernization and social change in rural \& urban Adolescence. 
H1. "There is no significant difference in the mean scores of the modernization among rural \& urban Adolescence."

Table-1, Showing the Mean, S.D. and't' Value of the Modernization

\begin{tabular}{|l|c|c|c|c|c|}
\hline $\begin{array}{c}\text { Sample } \\
\text { Group }\end{array}$ & N & Mean & S.D. & t & $\begin{array}{c}\text { Level of } \\
\text { Sig. }\end{array}$ \\
\hline Rural & 240 & 102.42 & 12.59 & 2.74 & 0.01 \\
\hline Urban & 240 & 105.08 & 8.38 & \\
\hline
\end{tabular}

As visible from the above table, the mean and S.D. of rural adolescence is $102.42 \& 12.59$ while that of the urban adolescence is $105.08 \& 8.38$ respectively. The t-ratio is 2.74 which is significant at 0.01 level of confidence. Therefore the hypothesis 1 is rejected.

As the mean score of urban area adolescence is higher than that of rural area adolescence therefore, it may be said that urban area adolescence has significantly higher level of modernization than their rural area adolescence. The result of present study of supported by Patel (1979) \& B. Gahu (2006) \& H. Patel (2012).

H2 "There is no significant difference in the mean scores of social change among rural and urban adolescence.

Table-2, Showing the Mean, S.D. and't' Value of Social change

\begin{tabular}{|l|c|c|c|c|c|}
\hline $\begin{array}{c}\text { Sample } \\
\text { Group }\end{array}$ & N & Mean & S.D. & t & $\begin{array}{c}\text { Level of } \\
\text { Sig. }\end{array}$ \\
\cline { 1 - 4 } Rural & 240 & 126.12 & 14.70 & 3.28 & 0.01 \\
\hline Urban & 240 & 130.64 & 15.67 & \\
\hline
\end{tabular}

As visible from the above table, the mean and S.D. of rural adolescence is $126.12 \& 14.70$ while that of the urban adolescence is $130.64 \& 15.67$ respectively. The t-ratio is 3.28 which is significant at 0.01 level of confidence. Therefore the hypothesis 2 is rejected.

As the mean score of urban area adolescence is higher than of rural area adolescence therefore, it may be said those urban areas have significantly higher level of social change than their rural area counterpart. The result of present study is supported by B. Gahu (2006).

H3 There exists no correlation between the modernization and social change of the Adolescence.

Table-3, Showing the Mean, S.D. and ' $t$ ' Value of the Modernization

\begin{tabular}{|l|c|c|}
\hline \multicolumn{1}{|c|}{ Variables } & N & r \\
\hline Modernization & 480 & \multirow{2}{*}{0.45} \\
\hline Social Change & 480 & \\
\hline
\end{tabular}




\section{Modernization and Social Change among Adolescence}

The table-3 showing the correlation between the modernization and social change of the Adolescence is ' $r$ ' value $=0.45$, is positive, it means the hypothesis is rejected as there is positive correlation between the modernization and social change of the adolescence.

\section{CONCLUSION:}

We can conclude by Data analysis as follows:

There was significant difference of the rural and urban adolescence on the modernization and social change. And there is a significant correlation between modernization and social change among adolescents.

\section{REFERENCES}

1. Ahluwalia S. P. (1985). Manual for comprehensive modernization inventory. National Psychological Corporation, Agra.

2. B. Gaha (2006). Modernization and social change among college students A Social Psychological Study. Unpublished thesis a Saurashtra University.

3. Giddens, A. (1991): Modernity and self-identity: self and society in the late modern age. Cambridge: Polity

4. H. T. Patel (2013). Attitude of Adolescents towards modernization in relation to certain variables international journal for research in education Vol.2 (7).

5. M. Kaur \& J. Kaur (2013). Aggression among adolescents in relation to modernization. Journal of Multidisciplinary Research. Vol.11, 31-40.

6. Patel, M. T. (1979). Attitude of post graduate student of Sardar Patel University towards modernization, Journal of Education Psychology, 37(3) 173-183.

7. Rostow, W.W., 1971. Politics and the Stages of Growth. Cambridge University Press, London. 